\section{TANGGUNG JAWAB PELAKU USAHA JASA PERPARKIRAN BAGI KONSUMEN KORBAN PENCURIAN KENDARAAN BERMOTOR DI KAWASAN PERBELANJAAN KOTA MANADO ${ }^{1}$ Oleh : Dheny Budhiono ${ }^{2}$}

\section{ABSTRAK \\ Masih banyak tempat-tempat usaha jasa} penitipan kendaraan bermotor (parkir) yang mencantumkan klausula baku, yaitu pusat perbelanjaan, mall dan lain-lain. Isi klausula baku yang biasa tercantum pada bukti atau karcis penitipan yakni bahwa pelaku usaha tidak bertanggung jawab dan memberikan ganti rugi jika terjadi kerusakan atau kehilangan barang yang dititipkan, melainkan menjadi tanggung jawab pemilik kendaran itu sendiri. Ketentuan tersebut mengindikasikan pelaku usaha berusaha mengalihkan tanggung jawab, yang seharusnya menjadi tanggung jawabnya berpindah menjadi tanggung jawab konsumen. Padahal sangat mungkin terjadinya kehilangan atau kerusakan kendaraan bermotor ketika kendaraan tersebut dititipkan dan berada dalam kekuasaan pelaku usaha. Dalam hal ini timbul ketidakadilan serta berpotensi merugikan konsumen. Perbuatan pelaku usaha tersebut bertentangan atau melanggar Pasal 1365, Pasal 1366 dan Pasal 1367 KUHPerdata serta Pasal 19 Undang-undang Nomor 8 Tahun 1999 tentang Perlindungan Konsumen. Menurut undang-undang tersebut diatas, bahwa segala kerusakan, pencemaran, kerugian, dan/atau kehilangan yang timbul/terjadi sebagai akibat dari pemanfaatan jasa perparkiran oleh konsumen perparkiran mutlak merupakan tanggung jawab pengelola parkir untuk memberikan ganti rugi baik berupa pengembalian uang atau penggantian barang dan/atau jasa yang sejenis atau setara nilainya. Konsumen selaku pengguna jasa perparkiran dapat menggugat pelaku usaha melalui Badan Penyelesaian Sengketa Konsumen atau badan peradilan apabila penyelenggaraan jasa perparkiran lalai atau kurang berhati-hati dalam memperdagangkan jasanya sehingga menyebabkan konsumen mengalami kerugian.

\footnotetext{
${ }^{1}$ Artikel Tesis. Dosen Pembimbing : Prof. Dr. Telly Sumbu, $\mathrm{SH}, \mathrm{MH}$; Dr. Johnny Lembong, $\mathrm{SH}, \mathrm{MH}$

${ }^{2}$ Mahasiswa pada Pascasarjana Universitas Sam Ratulangi, NIM. 1223208011
}

Dengan demikian konsumen secara pasti mendapatkan perlindungan dan kepastian hukum meskipun tidak melalui jalan yang mudah. Banyak kasus serupa juga dimenangkan oleh konsumen lainnya melalui putusan Peninjauan Kembali Mahkamah Agung. Putusan Mahkamah Agung tersebut selalu membatalkan klausula baku tentang pengelola parkir yang tidak bertanggung jawab atas kehilangan/kerusakan barang konsumen yang sekarang menjadi yurisprudensi.

Kata kunci: konsumen, pelaku usaha, klausula baku, tanggung jawab, ganti rugi

\section{PENDAHULUAN}

Berawal dari keprihatinan akan banyaknya kasus yang merugikan kepentingan konsumen serta didukung oleh ketidakberdayaan konsumen, maka kehadiran produk perundangundangan untuk melindungi kepentingan konsumen sangat diperlukan. Pemerintah, Dewan Perwakilan Rakyat (DPR), dan sejumlah lembaga yang memberikan perhatian kepada perlindungan konsumen kemudian berupaya untuk merumuskan produk hukum yang memberikan perlindungan yang memadai kepada konsumen di Indonesia. Pada akhirnya lahirlah UU No. 8 tahun 1999 tentang Perlindungan Konsumen yang disahkan pada tanggal 20 April 1999, dan mulai efektif setahun setelahnya (20 April 2000). ${ }^{3}$

Untuk menghadapi dan menyelesaikan masalah-masalah konsumen dari sisi hukum, maka dikeluarkan Undang-undang Perlindungan Konsumen (UUPK) yang dapat mencegah dan melarang adanya usaha yang berisiko menimbulkan kerugian bagi konsumen ketika akan menggunakan barang/jasa. Konsumen kita saat ini secara hukum sudah mendapatkan payung berupa undang-undang untuk melindungi kepentingan mereka. Seluruh pasal yang termuat dalam UUPK mempunyai ciri khusus dibandingkan dengan peraturan dan ketentuan lainnya yang mengatur hal yang sama. UUPK lebih bernuansa adanya sikap keberpihakan kepada konsumen tanpa

\footnotetext{
3 Heri Tjandrasari. Badan Penyelesaian Sengketa Konsumen ( BPSK ) dan Upaya Perlindungan Hukum Kepada Konsumen, diterbitkan oleh MaPPI-FHUP, tahun dan tanggal terbit tidak disebutkan, diakses dari www.pemantauperadilan.com, pada tanggal 20 Januari 2011.
} 
mengabaikan hak-hak pelaku usaha. Konsumen diberi hak dan kesempatan yang leluasa untuk mempertahankan kepentingannya. Hal ini mungkin bersifat reaktif atas fenomena dunia usaha yang didominasi oleh pelaku usaha. Dasar filosofi inilah yang secara yuridis menempatkan kedudukan UUPK menjadi lebih tegas dan jelas peruntukannya. ${ }^{4}$

Sejak UUPK disahkan, dalam implementasinya ternyata masih belum terlihat secara signifikan. Berbagai ketentuan yang ada dalam UUPK masih menjadi aturan yang sangat mudah diabaikan oleh pelaku usaha. Salah satu pelanggaran yang masih banyak terjadi ialah adanya pembuatan klausula baku (standard contract) dalam kegiatan usaha. Perjanjian atau klausula baku merupakan perjanjian yang formatnya sudah dibuat oleh salah satu pihak yang lebih dominan dan pihak lain tinggal menyetujui saja. Dikatakan bersifat "baku" karena baik perjanjian maupun klausula tersebut tidak dapat dan tidak mungkin dinegosiasikan atau ditawar-tawar oleh pihak lainnya. Dalam praktek kegiatan usaha, klausula baku dibuat oleh pelaku usaha, sedangkan konsumen sebagai pihak lain yang mau tidak mau harus menyetujui perjanjian dimaksud. Klausula baku, diantaranya lazim dijumpai pada lembar penitipan kendaraan bermotor (parkir), yang berupa ketentuan mengenai perlakuan pelaku usaha terhadap barang yang dititipkan. Sampai saat ini klausula baku yang dicantumkan pelaku usaha masih tidak sesuai dengan ketentuan yang diatur dalam UUPK. Tempattempat usaha yang masih banyak mencantumkan klausula baku dalam penitipan kendaraan bermotor (parkir) yaitu pusat perbelanjaan, mall dan lain-lain. Penulis mengambil sample beberapa tempat parkir kawasan perbelanjaan di Kota Manado yang masih mencantumkan klausula baku pada tiket/karcis parkir, antara lain: kawasan perbelanjaan Bahu Mall, Mega Mas, Manado Town Square dan Toko Buku Gramedia. Isi klausula baku yang biasa tercantum pada bukti atau karcis penitipan yakni bahwa pelaku usaha tidak bertanggung jawab jika terjadi kerusakan atau kehilangan barang yang dititipkan,

4 Tria Sasangka Putra, S.H., LL.M. Perlindungan Konsumen dalam Era Consumerism-Wise di Indonesia, Harian Pelita. ( 12 Januari 2006 ). melainkan menjadi tanggung jawab pemilik kendaran itu sendiri. Ketentuan tersebut mengindikasikan pelaku usaha berusaha mengalihkan tanggung jawab, yang seharusnya menjadi tanggung jawabnya berpindah menjadi tanggung jawab konsumen. Padahal sangat mungkin terjadinya kehilangan atau kerusakan kendaraan bermotor ketika kendaraan tersebut dititipkan dan berada dalam kekuasaan pelaku usaha. Dalam hal ini timbul ketidakadilan serta berpotensi merugikan konsumen.

Beberapa kali terjadi kasus kehilangan kendaraan bermotor di tempat parkir kawasan perbelanjaan Kota Manado. Ketika konsumen sebagai korban menanyakan ke pihak manajemen perparkiran bermaksud minta ganti rugi, tetapi pihak manajemen perparkiran menjawab tidak tahu-menahu tentang ranmor yang hilang dan bukan tanggungjawab dari pihak manajemen perparkiran melainkan tanggungjawab sendiri (korban). Jadi, korban curanmor yang ranmornya masih hilang tidak ada satupun yang mendapat ganti rugi oleh manajemen atau pelaku usaha perparkiran.

Hal tersebut menunjukkan bahwa pelaku usaha perparkiran telah mengalihkan tanggungjawab kepada pihak lain atau konsumen sendiri atas kehilangan barang/ranmor di kawasan perbelanjaan serta mengesampingkan hak-hak dan berlaku tidak adil terhadap konsumen selaku korban pencurian. Selain itu perlindungan, rasa keadilan dan kepastian hukum tidak diperoleh konsumen sebagaimana diamanatkan undangundang.

Dengan kehadiran UUPK, sebenarnya potensi ketidakadilan yang dialami konsumen bisa diminimalisir. Sebagaimana diatur dalam UUPK, jenis klausula baku yang dilarang digunakan oleh pelaku usaha sebenarnya sudah sangat berpihak pada konsumen. Konsekuensi jika berbagai klausula baku itu tidak berlaku lagi maka akan banyak hal yang dapat meringankan konsumen ketika mendapati perlakuan tidak adil dari pelaku usaha.

Berbagai impikasi dari berlakunya peraturan tentang klausula baku dalam UUPK ialah, pelaku usaha tidak boleh mengalihkan tanggung jawab, tidak bisa menolak memberikan ganti kerugian kepada konsumen, sehingga jika terjadi kerusakan atau kehilangan konsumen akan terhindar dari potensi kerugian. 
Konsumen bisa menuntut ganti kerugian dengan barang lain atau mengembalikan barang tersebut dengan uang.

Namun yang menjadi persoalan sampai saat ini adalah masih rendahnya kesadaran semua pihak dalam menegakkan peraturan ini, terutama kalangan pelaku usaha. Dari pengamatan penulis di berbagai tempat usaha di Kota Manado yang menyediakan jasa parkir, masih banyak dijumpai adanya klausula baku dalam karcis tanda parkirnya yang tidak sesuai dengan UUPK. Selain itu di Kota Manado sendiri belum ada Badan Penyelesaian Sengketa Konsumen (BPSK) ataupun lembaga perlindungan konsumen swadaya masyarakat yang berfungsi untuk menyelesaikan sengketa konsumen diluar pengadilan, sehingga konsumen selaku korban pencurian kendaraan bermotor tidak memperoleh haknya yaitu mendapatkan pertanggungjawaban dan ganti rugi dari pelaku usaha jasa perparkiran.

\section{PERUMUSAN MASALAH}

1. Bagaimana tanggung jawab pelaku usaha jasa perparkiran bagi konsumen korban pencurian kendaraan bermotor di kawasan perbelanjaan Kota Manado berdasarkan KUHPerdata dan UU Nomor 8 Tahun 1999 tentang Perlindungan Konsumen?

2. Bagaimana perlindungan dan kepastian hukum yang diperoleh korban pencurian kendaraan bermotor sebagai konsumen pengguna jasa layanan parkir?

\section{METODOLOGI PENELITIAN}

Penulisan penelitian ini menggunakan pendekatan yuridis normatif, pendekatan hukum normatif (disebut juga penelitian hukum doktrinal) yaitu suatu penelitian atas hukum (termasuk asas hukum) dan kaidah (norm). ${ }^{5}$ Lokasi penulisan penelitian ini menunjuk di pustakaan Pasca Sarjana IImu Hukum Universitas Sam Ratulangi Manado. Jenis penelitian ini dikategorikan sebagai penelitian yang bersifat deskriptif analitis berupa penggambaran terhadap perumusan masalah tersebut. Data penelitian adalah bahan sediaan yang berupa informasi bagi peneliti untuk

\footnotetext{
${ }^{5}$ Universitas Sam Ratulangi Pedoman Penyelenggaraan Pendidikan Progam Studi S2 IImu Hukum Pasca Sarjana Universitas Sam Ratulangi. Manado, 2013, hal 68.
}

dianalisa. Ada dua jenis data, yaitu : Data primer dan Data sekunder. Selanjutnya sumber data dari penelitian hukum terdiri dari dua, sumber primer dan sekunder.

Ada tiga macam alat pengumpulan data, yaitu studi dokumen atau bahan pustaka, pengamatan atau observasi dan wawancara atau interview. Studi dokumen lazimnya digunakan dalam penelitian kepustakaan. Dalam penelitian hukum, penelitian kepustakaan yang dilakukan adalah yang bersifat yuridis-normatif. ${ }^{6}$ Namun dalam penelitian ini data dikumpulkan dengan dua cara, yaitu wawancara dan studi dokumen. Data yang diperoleh dengan metode diskriptif kualitatif, yaitu data yang diperoleh disajikan secara deskriptif dan dianalisis secara kualitatif (content analysis) dengan langkah-langkah sebagai berikut: 1) Data penelitian dikualifisasikan sesuai dengan permasalahan penelitian; 2) Hasil klasifikasi kemudian disistemasikan; 3) Data yang telah disistemasikan kemudian dianalisis untuk dijadikan dasar dalam pengambilan kesimpulan.

\section{HASIL DAN PEMBAHASAN}

Berdasarkan data yang diperoleh penulis, telah terjadi banyak kejadian pencurian kendaraan bermotor (curanmor) di kawasan perbelanjaan dan mall di Kota Manado yang dipungut biaya parkir oleh pelaku usaha perparkiran, antara lain: tahun 2012 terjadi 52 kasus curanmor dan tahun 2013 telah terjadi 48 kasus curanmor. ${ }^{7}$ Dari jumlah total 100 korban curanmor, lima kendaraan bermotor (ranmor) ditemukan, sedangkan sisanya 95 ranmor belum ditemukan/masih hilang. Dari sekian banyak kasus kehilangan kendaraan bermotor di tempat parkir, tidak ada satupun tanggung jawab ataupun yang mendapat ganti rugi oleh manajemen atau pelaku usaha jasa perparkiran. Hal tersebut jelas bertentangan dengan asas dan tujuan dalam UUPK, karena dalam asas UUPK jelas disebutkan bahwa "Perlindungan konsumen berasaskan manfaat, keadilan, keseimbangan, keamanan dan keselamatan konsumen, serta kepastian hukum".

\footnotetext{
${ }^{6}$ lbid.

7 Laporan Tahunan Polresta Manado TA. 2012 dan TA. 2013 tentang Laporan Kesatuan.
} 
Dari sekian banyak kasus tersebut, sayangnya pihak korban atau konsumen tidak ada yang melaporkan atau menggugat pelaku usaha, baik melalui pengadilan maupun diluar pengadilan. Konsumen binggung mau berbuat apa dan mau melaporkan kemana perihal pertanggungjawaban pelaku usaha dan permintaan ganti rugi atas musibah yang dialaminya tersebut. Hal tersebut dikarenakan kurangnya pengetahuan masyarakat dibidang perlindungan konsumen dan kurang memahami isi dari UUPK serta belum adanya lembaga perlindungan konsumen swadaya masyarakat ataupun BPSK di Kota Manado sebagaimana diamanatkan dalam UUPK.

Ada dua hubungan hukum antara pelaku usaha dengan konsumen pertama hubungan hukum mungkin telah ada terlebih dahulu antara pelaku usaha dengan konsumen yang berupa sebuah hubungan kontraktual (hubungan perjanjian), tetapi mungkin juga tidak pernah ada hubungan hukum sebelumnya dan keterikatan secara hukum justru lahir setelah timbul peristiwa yang merugikan konsumen. $^{8}$ Konsumen jasa parkir Kota Manado, sering mengalami hubungan hukum yang terakhir, yaitu setelah adanya peristiwa kehilangan kendaraan bermotor yang menyebabkan kerugian konsumen baru timbul hubungan hukum.

Suatu hal yang nyata, bahwa mengelak dari suatu tanggung jawab bagi sebagian orang merupakan hal yang wajar karena dengan sikap yang tidak bertanggung jawab tersebut mereka mendapatkan suatu keuntungan, bahkan suatu perbuatan yang tidak bertanggung jawab tersebut didukung oleh lingkungan dekatnya, teman-temannya, anak buahnya, atasannya, atau keluarganya. Menurut Jimli Asshiddiqie dan M. Ali Safa'at, suatu konsep terkait dengan konsep kewajiban hukum adalah konsep tanggung jawab hukum (legal liability). Seseorang dikatakan secara hukum bertanggung jawab untuk suatu perbuatan tertentu adalah bahwa dia dapat dikenakan

\footnotetext{
8 Widijantoro. Ruang Lingkup Persoalan Penegakan Hukum Pelindungan Konsumen Indonesia ( Diktat Hukum Persaingan dan Perlindungan Konsumen, Program Studi Magister Hukum ). Yogyakarta : Universitas Atmadjaya, 2001, hal 101.
}

suatu sanksi dalam kasus perbuatan yang berlawanan. $^{9}$

Namun dalam penulisan tesis ini, Peneliti akan membahas tiga model tanggung jawab hukum, antara lain:

a. Tanggung jawab dengan unsur kesalahan (kesengajaan dan kelalaian) sebagaimanapun terdapat dalam Pasal 1365 KUHPerdata.

b. Tanggung jawab dengan unsur kesalahan khususnya kelalaian sebagaimana terdapat dalam Pasal 1366 KUHPerdata.

c. Tanggung jawab mutlak (tanpa kesalahan) sebagaimana terdapat dalam Pasal 1367 KUHPerdata.

Pada pasal-pasal KUHPerdata yang telah disebutkan diatas, secara umum memberikan gambaran mengenai batasan ruang lingkup akibat dari suatu perbuatan melawan hukum. Akibat perbuatan secara hukum secara yuridis mempunyai konsekwensi terhadap pelaku maupun orang-orang yang mempunyai hubungan hukum dalam bentuk pekerjaan yang menyebabkan timbulnya perbuatan melawan hukum. Jadi, akibat yang timbul dari suatu perbuatan melawan hukum akan diwujudkan dalam bentuk ganti kerugian terhadap korban yang mengalami.

Berdasarkan Pasal 1365 KUHPerdata, apabila pelaku usaha jasa perparkiran tidak melaksanakan kewajibannya selaku pelaku usaha dalam arti terjadi kelalaian dan pembiaran oleh petugas parkir saat melakukan tugasnya, sehingga ada kerugian yang dialami konsumen sebagai pengguna jasa perparkiran, maka pelaku usaha wajib mengganti kerugian yang dialami konsumen tersebut. Penyelenggaraan jasa perparkiran yang berbentuk Perseroan Terbatas dapat digugat melakukan perbuatan melawan hukum berdasarkan Pasal 1365 KUHPerdata.

Berdasarkan Pasal 1366 KUHPerdata, konsumen selaku pengguna jasa perparkiran dapat menggugat pelaku usaha melalui BPSK atau badan peradilan apabila penyelenggaraan jasa perparkiran lalai atau kurang berhati-hati dalam memperdagangkan jasanya sehingga menyebabkan konsumen mengalami kerugian.

\footnotetext{
9 Jimli Asshiddiqie, dan M. Ali Safa'at. Teori Kelsen Tentang Hukum. Jakarta : Sekretariat Jenderal dan Kepaniteraan Mahkamah Konstitusi RI Jakarta, 2006.
} 
Berdasarkan fakta-fakta yang diperoleh dilapangan, bahwa pelaku usaha jasa perparkiran di kawasan perbelanjaan Kota Manado masih berbuat lalai, sehingga masih ada celah yang memungkinkan terjadinya perbuatan melawan hukum seperti pengrusakan dan pencurian.

Mengacu pada isi Pasal 1367 KUHPerdata, bahwa seseorang/pelaku usaha wajib bertanggung jawab untuk memberikan ganti rugi tidak hanya disebabkan oleh perbuataannya sendiri, akan tetapi juga karena perbuatan-perbuatan orang-orang yang menjadi tanggungannya atau disebabkan oleh barang-barang yang berada di bawah pengawasannya seperti tanggung jawab majikan-majikan dan mereka yang mengangkat orang-orang lain untuk mewakili urusan-urusan mereka terhadap kerugian yang ditimbulkan sebagai akibat dari pekerjaan yang dilakukan oleh pelayan-pelayan atau bawahan-bawahan mereka.

Dengan demikian, bahwa segala sesuatu yang terjadi pada wilayah perparkiran atau dibawah pengawasan manajemen perparkiran merupakan tanggung jawab dari pelaku usaha jasa perparkiran termasuk petugas-petugas parkir yang secara langsung maupun tidak langsung mengurusi perparkiran didalam wilayah parkirnya. Tanggung jawab yang harus ditanggung oleh pelaku usaha tidak hanya sebatas pada barang-barang yang rusak atau hilang, namun termasuk segala kerugian yang dialami oleh konsumen, baik yang bersifat kerugian materiil maupun immateriil atau kerugian atas ketidak nyamanan pada pelayanan perparkiran yang ditimbulkan oleh pelaku usaha jasa perparkiran.

Untuk lebih melindungi konsumen dari sikap pelaku usaha yang tidak bertanggung jawab, selain KUHPerdata, tanggung jawab pelaku usaha secara jelas diatur dalam Bab VI Pasal 19 sampai dengan Pasal 28 UUPK. Praduga selalu bertanggung jawab (Presumption of liability) adalah prinsip praduga selalu bertanggung jawab sampai ia dapat membuktikan ia tidak bersalah. Jadi beban pembuktian ada pada si tergugat. Tampak beban pembuktian terbalik (omkering van bewijslas) diterima dalam prinsip tersebut. UU Perlindungan Konsumen mengadopsi pembuktian terbalik ini ditegaskan dalam Pasal 19, 22, dan 23 UUPK. ${ }^{10}$ Salah satu pertimbangan dibuat dan disahkannya UUPK ialah untuk menumbuhkembangkan sikap perilaku usaha yang bertanggung jawab, dan salah satu tujuan perlindungan konsumen yaitu menumbuhkan kesadaran pelaku usaha mengenai pentingnya perlindungan konsumen sehingga tumbuh sikap yang jujur dan bertanggung jawab dalam berusaha.

Perihal kehilangan kendaraan bermotor dengan menggunakan jasa perparkiran seharusnya mendapat ganti rugi oleh pelaku usaha jasa perparkiran, karena sudah jelas diatur dalam Pasal 7 UUPK tentang kewajiban pelaku usaha terutama huruf $f$, Pasal 19 UUPK tentang tanggung jawab pelaku usaha, Pasal 22 UUPK tentang pembuktian ada tidaknya unsur kesalahan dalam kasus pidana dan Pasal 23 UUPK tentang gugatan melalui BPSK atau peradilan.

Berdasarkan pada uraian mengenai tanggung jawab menurut KUHPerdata dan UUPK diatas, penulis menyimpulkan bahwa pada intinya dalam lingkup perparkiran terutama perparkiran yang dikelola secara profesional harus mengacu pada Pasal 1365, Pasal 1366, Pasal 1367 KUHPerdata dan Pasal 19 UUPK, segala kerusakan, pencemaran, kerugian, dan/atau kehilangan yang timbul/terjadi sebagai akibat dari pemanfaatan jasa perparkiran oleh konsumen perparkiran mutlak merupakan tanggung jawab pengelola parkir untuk memberikan ganti rugi baik berupa pengembalian uang atau penggantian barang dan/atau jasa yang sejenis atau setara nilainya yang sesuai dengan ketentuan peraturan perundang-undangan yang berlaku.

Sesuai dengan the due care theory atau teori perhatian, setiap pelaku usaha berkewajiban untuk memberikan perhatian atau menyampaikan kepada konsumen setiap produk atau jasa yang mereka jual. Kelebihan ataupun kekurangan produk atau jasa yang pelaku usaha jual wajib diketahui oleh konsumen selaku pengguna produk atau jasa tersebut, agar konsumen terhindar dari luka

\footnotetext{
${ }^{10}$ Sukarmi. 2005. "Tanggung Jawab Pelaku Usaha Atas Kerugian Konsumen Yang Disebabkan Oleh Perjanjian Baku ( Standard Contract) Dalam Transaksi Elektronik. Prinsip Tanggung Jawab". Melalui vanbanjarechts.wordpress.com/2013/01/01/prinsiptanggung-jawab/
} 
atau kerugian yang disebabkan oleh produk atau jasa yang pelaku usaha jual.

Demikian juga dengan usaha jasa perparkiran, pelaku usaha jasa perparkiran wajib menyampaikan informasi atau konsumen wajib mengetahui bagaimana situasi dan kondisi perparkiran yang pelaku usaha sediakan. Pelaku usaha bisa menyajikan informasi-informasi penting yang harus diketahui oleh konsumen, baik tentang faktor keamanan, tarif parkir, jumlah petugas parkir, fasilitas yang disediakan dan lain-lain. Dengan demikian, pelaku usaha melaksanakan kewajiban dan tanggung jawabnya selaku penyedia jasa layanan parkir kepada konsumen.

The social cost view of the manufacturer's duties, teori ini menekankan pada kewajiban pelaku bisnis atau produsen untuk memberikan ganti rugi terhadap kerugian yang dialami oleh konsumen akibat produk yang digunakan. ${ }^{11}$ Menurut teori diatas serupa dengan teori dan aturan-aturan yang digunakan oleh penulis, bahwa pelaku usaha mempunyai kewajiban untuk memberikan ganti rugi atas kerugian yang dialami oleh konsumen akibat dari penggunaan produk dan/atau jasa.

Kerugian yang diderita seseorang secara garis besar dapat dibagi atas dua bagian, yaitu kerugian yang menimpa diri dan kerugian yang menimpa harta benda seseorang. Sedangkan kerugian harta benda sendiri dapat berupa kerugian nyata yang dialami serta kehilangan keuntungan yang diharapkan. ${ }^{12}$

Secara teoritis penyelesaian sengketa dapat dilakukan melalui dua cara. Cara penyelesaian sengketa pertama melalui proses litigasi di dalam pengadilan, kemudian berkembang proses penyelesaian sengketa melalui kerjasama (kooperatif) di luar pengadilan. Proses litigasi menghasilkan putusan yang bersifat pertentangan (adversarial) yang belum mampu merangkul kepentingan bersama, bahkan cenderung menimbulkan masalah baru, lambat dalam penyelesaiannya, membutuhkan biaya yang mahal, tidak responsif, dan

\footnotetext{
${ }^{11}$ Pratanto, C. 2012. "Perlindungan Konsumen". Melalui http://cpratanto.blogspot.com/2012/12/perlindungankonsumen.html

${ }^{12}$ Ahmadi Miru dan Sutarman Yodo. Hukum Perlindungan Konsumen. Jakarta : Raja Grafindo Persada, 2004, hal 133.
}

menimbulkan permusuhan diantara pihak yang bersengketa. ${ }^{13}$

Berdasarkan pada Pasal 45 ayat ( 2 ) dan Pasal 47 UUPK sebagaimana tersebut diatas, penyelesaian sengketa konsumen di luar pengadilan dapat ditempuh dengan dua cara, yaitu: ${ }^{14}$ 1) Penyelesaian tuntutan ganti kerugian seketika; 2)Penyelesaian tuntutan ganti kerugian melalui BPSK. Seorang konsumen yang dirugikan karena mengkonsumsi barang dan/atau memanfaatkan jasa, hanya akan mendapatkan ganti rugi apabila mengajukan permintaan atau tuntutan atas hal tersebut. Permintaaan atau penuntutan penggantian kerugian ini mutlak dilakukan oleh konsumen yang merasa berhak untuk mendapatkannya.

Melihat isi dari Pasal 19 UUPK, dapat disimpulkan bahwa konsumen yang telah dirugikan sebagai akibat dari mengkonsumsi barang dan/atau memanfaatkan jasa dapat mengajukan tuntutan langsung kepada pelaku usaha, dan pelaku usaha harus memberi tanggapan dan/atau penyelesaian dalam jangka waktu tujuh hari sejak pengajuan tuntutan diterima oleh pelaku usaha. Penyelesaian sengketa yang dimaksudkan disini bukanlah penyelesaian yang rumit dan melalui pemeriksaan mendalam terlebih dahulu, melainkan bentuk penyelesaian sederhana dan praktis yang ditempuh dengan jalan damai.

Sebagai suatu penyelesaian perdamaian, maka tetap terbuka kemungkinan untuk menuntut pelaku usaha secara pidana. Penyelesaian sengketa konsumen secara damai dimaksudkan penyelesaian sengketa antar para pihak, dengan atau tanpa kuasa/pendamping bagi masing-masing pihak, melalui cara-cara damai. Dengan cara penyelesaian sengketa konsumen secara damai ini, sesungguhnya ingin diusahakan bentuk penyelesaian yang mudah, murah, dan cepat. Dasar hukum penyelesaian tersebut terdapat pula dalam KUHPerdata (Buku Ke-III, Bab 18, Pasal 1851 s/d 1854 tentang Perdamaian/Dading). ${ }^{15}$

Pasal 1 angka 1 UUPK jo. Pasal 1 angka 6 Peraturan Mendag No. 17 Tahun 2007

\footnotetext{
${ }^{13}$ Rachmadi Usman. Pilihan Penyelesaian Sengketa di Luar Pengadilan. Bandung : PT. Citra Aditya Bakti, 2003, hal 3.

14 Janus Sidabalok. Hukum Perlindungan Konsumen di Indonesia. Bandung : PT Citra Aditya Bakti, 2010, hal 145.

${ }_{15}$ Az Nasution, 2002. Hukum Perlindungan Konsumen: Suatu Pengantar. Cet. 2. Jakarta : Diadit media, hal 225.
} 
mendefinisikan BPSK sebagai badan yang bertugas menangani dan menyelesaikan sengketa antara pelaku usaha dan konsumen yang menuntut ganti rugi atas kerusakan, pencemaran dan/atau yang menderita kerugian akibat dari mengkonsumsi barang dan/atau memanfaatkan jasa. ${ }^{16}$ Penyelesaian sengketa konsumen melalui BPSK dilakukan secara sederhana, cepat dan murah, dengan tujuan untuk mencari kesepakatan tentang bentuk dan besarnya ganti rugi dan/atau mengenai tindakan tertentu untuk menjamin tidak akan terjadi kembali atau tidak akan terulang kembali kerugian yang diderita konsumen. ${ }^{17}$ Suatu gugatan konsumen kepada pelaku usaha dan atas kewenangannya, BPSK dapat menyelesaikan sengketa konsumen dengan cara konsiliasi, mediasi dan arbitrase.

a. Perlindungan Dan Kepastian Hukum Yang Diperoleh Korban Pencurian Kendaraan Bermotor Sebagai Konsumen Pengguna Jasa Layanan Parkir

Dalam perkembangannya, perlindungan konsumen di Indonesia masih belum mengakomodir kepentingan masyarakat dibidang perlindungan konsumen. Banyaknya masalah yang terjadi tentang perlindungan konsumen, belum bisa teratasi dengan baik dan belum memberikan perlindungan serta kepastian hukum sesuai dengan yang diharapkan masyarakat.

Kepastian hukum sebagai salah satu tujuan hukum, dimana asas kepastian hukum telah tertuang dalam Pasal 2 UUPK. Adapun penjelasan asas kepastian hukum ialah baik pelaku usaha maupun konsumen mentaati hukum dan memperoleh keadilan dalam penyelenggaraan perlindungan konsumen, serta negara menjamin kepastian hukum. Bahwa UUPK menjamin terwujudnya kepastian hukum dengan mengatur beberapa pasal yang harus ditaati oleh masyarakat, khususnya pelaku usaha. Pasal-pasal yang mengakomodir tentang kepastian hukum, antara lain: Pasal 8 UUPK tentang perbuatan yang dilarang bagi pelaku usaha, Pasal 18 UUPK tentang pencantuman klausula baku, Pasal 19 UUPK tentang tanggung jawab pelaku usaha, Pasal 45

\footnotetext{
${ }^{16}$ Pasal 1 angka 6 Peraturan Menteri Perdagangan Nomor 17/M-Dag/Per/4/2007

17 Ibid, Pasal 2
}

sampai Pasal 48 UUPK tentang mekanisme penyelesaian sengketa dan Pasal 61 sampai Pasal 63 UUPK tentang ketentuan pidana.

Keberadaan klausula baku dalam perjanjian didasarkan pada asas kebebasan berkontrak. Pada umumnya klausula yang dibuat oleh satu pihak sangat merugikan konsumen yang memiliki posisi lemah, karena beban atau kewajiban yang seharusnya menjadi tanggung jawab pelaku usaha dengan adanya klausula tersebut menjadi beban konsumen. ${ }^{18}$ Hakekat klausula baku dalam perjanjian tidak lain adalah adanya pembagian beban resiko yang layak, namun dalam praktik makna klausula baku disalahgunakan oleh mereka yang memiliki keunggulan ekonomi dengan maksud untuk membebaskan diri dari beban tanggung jawab yang berlebihan tetapi juga sampai pada pengalihan tanggung jawab. Oleh karena itu perlu adanya pembatasan terhadap pengunaan klausula baku dalam perjanjian.

Sejak berlakunya UUPK, pelaku usaha termasuk pengelola parkir wajib menyesuaikan klausula baku yang bertentangan dengan UUPK. Dalam hal pelaku usaha tetap melanggar ketentuan sebagaimana dimaksud dalam Pasal 18 UUPK tersebut akan diberikan sanksi, baik sanksi pidana penjara atau pidana denda sebagaimana diatur dalam Pasal 62 ayat ( 1 ) UUPK.

Atas kebatalan demi hukum dari klausula baku sebagaimana disebutkan dalam Pasal 18 ayat (3), Pasal 18 ayat (4) UUPK selanjutnya mewajibkan para pelaku usaha untuk menyesuaikan klausula baku yang bertentangan dengan UUPK ini. Jadi apabila kasus mengenai klausula baku dimajukan ke sidang pengadilan, pada sidang pertama hakim harus menyatakan bahwa perjanjian atau klausula itu batal demi hukum. ${ }^{19}$

Sengketa konsumen secara umum timbul karena tidak terpenuhinya hak konsumen atas barang dan/atau jasa yang ditawarkan oleh pelaku usaha dan tidak terpenuhinya kewajiban dan tanggung jawab pelaku usaha sebagaimana

\footnotetext{
${ }^{18}$ Ahmadi Miru dan Sutarman Yodo. Hukum Perlindungan Konsumen. Cet.1. Jakarta : Rajawali Press, 2004, hal 107.

${ }^{19}$ Dony Lanazura. Ketentuan Hukum (Baru) yang Diatur dalam UU Perlindungan Konsumen dan Mekanisme Penyelesaian Sengketa. Makalah, disampaikan pada Program Pembekalan PPDN, diadakan Yayasan Patra Cendekia. Jakarta, 4 Nopember 2000, hal 3.
} 
diatur dalam UUPK. Pada umumnya sengketa yang timbul dalam lingkup usaha perparkiran adalah sengketa yang bersumber dari hukum dimana pengelola parkir tidak memenuhi kewajibannya dan/atau bahkan mengalihkan sebagian atau seluruh tanggung jawabnya kepada konsumen parkir seperti dalam hal tidak mau bertanggung jawab terhadap hilangnya kendaraan konsumen parkir yang diparkir di dalam area parkir yang dikelolannya dengan aling-aling bahwa hal tersebut telah diperjanjikan didalam karcis parkir dan konsumen parkir dianggap setuju dengan isi perjanjian di dalamnya.

Pasal 48 UUPK menyebutkan bahwa penyelesaian sengketa melalui jalur pengadilan mengacu kepada ketentuan yang berlaku dalam peradilan umum dengan memperhatikan ketentuan Pasal 45 UUPK. Selain itu, menurut ayat ( 1 ), Pasal 48 penyelesaian sengketa dapat pula dilakukan diluar jalur pengadilan. Penyelesaian diluar jalur pengadilan ini dapat dilakukan dengan memanfaatkan Badan Penyelesaian Sengketa Konsumen (BPSK) sebagaimana bunyi Pasal 49 sampai dengan Pasal 58 UUPK. $^{20}$

Gugatan melalui pengadilan hanya dapat di tempuh jika upaya di luar pengadilan dinyatakan tidak berhasil oleh salah satu pihak atau oleh para pihak yang bersengketa. Ini berarti penyelesaian sengketa melalui pengadilan tetap dibuka setelah para pihak gagal menyelesaikan sengketa mereka di luar Pengadilan. ${ }^{21}$

Ternyata banyak kasus yang dimenangkan oleh para pengguna jasa parkir lainnya melalui putusan Peninjauan Kembali (PK) Mahkamah Agung Seperti pada hilangnya kendaraan Afifah Dewi, Sumito Y. Viansyah dan Vovo Budiman. Putusan Mahkamah Agung tersebut selalu membatalkan klausul tentang pengelola parkir tidak bertanggung jawab atas kehilangan/kerusakan barang. Maka

\footnotetext{
${ }^{20}$ Heri Tjandrasari. 2003. Badan Penyelesaian Sengketa Konsumen ( BPSK ) Dan Upaya Perlindungan Hukum Bagi Konsumen, 05 Jun 2003, 14:00:15 WIB pemantauperadilan.com. Melalui http://www.pemantauperadilan.com/detil/detil.php?id=9 $3 \&$ tipe $=$ opini $[26 / 2 / 14]$

${ }^{21}$ Muchsin. Tugas dan Wewenang Peradilan Terhadap Putusan Badan Penyelesaian Sengketa Konsumen, dalam Varia Peradilan, No. 278 Januari 2009. Jakarta : Mahkamah Agung Republik Indonesia, 2009, hal 16.
}

berdasarkan beberapa putusan Mahkamah agung tersebut, kini pengelola parkir sudah tidak seenaknya lagi untuk tidak mau bertanggung jawab bilamana kendaran atau barang milik pengguna jasa parkir hilang.

Satu hal lagi yang tidak diatur dalam UUPK ialah tidak ada bab yang memuat atau mengatur tentang asuransi, baik dari pelaku usaha maupun dari konsumen. Padahal asuransi sangat penting dikaitkan dengan perlindungan konsumen, selain itu dalam UUPK telah disinggung mengenai pelaku usaha, konsumen, tanggung jawab, kerugian, kompensasi, ganti rugi dan lain sebagainya. Termasuk dalam hal perparkiran yang besar kemungkinan timbul resiko di area perparkiran serta persengketaan antara pelaku usaha dan konsumen. Alangkah bagusnya seandainya masalah asuransi dimuat secara detail, agar tujuan dari perlindungan konsumen lebih tercapai, sehingga perlindungan dan kepastian yang diharapkan masyarakat dapat terwujud.

Melalui pemakaian asuransi parkir, maka para pelaku usaha merasa aman dan mendapat jaminan bahwa apabila terjadi kehilangan atau kerusakan di area perparkiran maka itu bukan menjadi tanggung jawab pelaku usaha lagi, karena telah dialihkan kepada pihak asuransi. Sehingga bila konsumen mengajukan klaim ganti rugi atas kerusakan atau kehilangannya maka pelaku usaha bisa mengganti tanpa harus mengalami kerugian pada harta kekayaannya.

Pelaksanaan asuransi parkir ini ditujukan untuk memberikan kemudahan bagi pihak konsumen dan pihak pengelola parkir. Sehingga segala risiko yang mungkin terjadi di area parkir tidak akan memberatkan salah satu pihak, pihak konsumen maupun pihak pengelola akan mendapatkan keuntungan tersendiri dari pemakaian asuransi parkir ini.

Berdasarkan penjelasan di atas dapat dikatakan bahwa apabila pihak konsumen tidak mendapatkan ganti rugi sebagimana yang dikemukakan oleh pihak pengelola parkir maka konsumen dapat mengajukan gugatan penyelesaian sengketa konsumen di luar ataupun di dalam pengadilan seperti yang dirumuskan dalam Pasal 23 jo. Pasal 45 ayat ( 2 ) UUPK. Sehingga konsumen secara pasti mendapatkan ganti kerugian meskipun tidak melalui jalan yang mudah, karena harus melalui gugatan penyelesaian sengketa terlebih dahulu. 


\section{PENUTUP}

1. Kesimpulan

a. Yang terjadi di Kota Manado selama ini, pelaku usaha jasa perparkiran selalu menolak atau tidak mau bertanggung jawab apalagi memberikan ganti rugi atas kerusakan maupun kehilangan kendaraan bermotor konsumen. Dalam lingkup perparkiran terutama perparkiran yang dikelola secara profesional harus mengacu pada Pasal 1365, Pasal 1366 dan Pasal 1367 KUHPerdata serta Pasal 19 UUPK. Apabila pelaku usaha jasa perparkiran tidak melaksanakan kewajibannya selaku pelaku usaha, sehingga ada kerugian yang dialami konsumen sebagai pengguna jasa perparkiran, maka pelaku usaha wajib mengganti kerugian yang dialami konsumen. Segala kerusakan, pencemaran, kerugian, dan/atau kehilangan yang timbul/terjadi sebagai akibat dari pemanfaatan jasa perparkiran oleh konsumen perparkiran mutlak merupakan tanggung jawab pengelola parkir untuk memberikan ganti rugi baik berupa pengembalian uang atau penggantian barang dan/atau jasa yang sejenis atau setara nilainya, atau perawatan kesehatan dan/atau pemberian santunan yang sesuai dengan ketentuan peraturan perundangundangan yang berlaku.

b. Pelaku usaha jasa perparkiran dalam menjalankan usahanya sebaiknya tidak melanggar isi dari UUPK, fakta yang ditemukan masih adanya klausula baku pengalihan tanggung jawab yang dicantumkan dalam karcis parkir sehingga bertentangan dengan Pasal 18 UUPK. Namun demikian apabila pelaku usaha menghindar dari tanggung jawabnya dan konsumen tidak mendapatkan ganti rugi dalam hal terjadinya kerusakan maupun kehilangan kendaraan bermotor dalam wilayah perparkiran, maka konsumen dapat mengajukan gugatan penyelesaian sengketa konsumen di luar ataupun di dalam pengadilan seperti yang dirumuskan dalam Pasal 23 jo. Pasal 45 ayat ( 2 ) UUPK. Agar konsumen secara pasti mendapatkan ganti kerugian meskipun tidak melalui jalan yang mudah, karena harus melalui gugatan penyelesaian sengketa terlebih dahulu. Banyak kasus serupa juga dimenangkan oleh konsumen lainnya melalui putusan Peninjauan Kembali (PK) Mahkamah Agung. Putusan Mahkamah Agung tersebut selalu membatalkan klausula baku tentang pengelola parkir yang tidak bertanggung jawab atas kehilangan/kerusakan barang konsumen yang sekarang menjadi yurisprudensi. Dengan demikian, maka konsumen pengguna jasa layanan parkir mendapatkan perlindungan dan kepastian hukum sesuai dengan asas dan tujuan perlindungan konsumen.

\section{Saran}

a. Beberapa hal yang menjadi kelemahan dalam UUPK perihal pemberian ganti rugi, antara lain: tata cara atau mekanisme tentang penggantian atau pemberian ganti rugi tidak dijelaskan secara rinci, apa dan bagaimana langkahlangkah yang harus dilakukan konsumen apabila konsumen dirugikan oleh pelaku usaha. Kriteria kehilangan atau kerusakan yang mendapatkan ganti rugi sejenis atau setara nilainya, serta kriteria kesalahan konsumen sehingga tidak mendapatkan ganti rugi. Hal-hal yang telah disebutkan diatas, seharusnya dituangkan lebih detail dalam UUPK. Sedangkan di Kota Manado sendiri peran pemerintah dalam perlindungan konsumen masih belum terlihat, belum ada BPSK ataupun lembaga perlindungan konsumen swadaya masyarakat yang berfungsi untuk menampung keluhan masyarakat ataupun menyelesaikan sengketa konsumen diluar pengadilan. Tiap-tiap provinsi, kabupaten dan kota wajib ada dan dibentuk BPSK ataupun lembaga perlindungan konsumen swadaya masyarakat.

b. Didalam UUPK sebaiknya memuat tentang asuransi, baik dari pelaku usaha 
maupun dari konsumen. Karena asuransi sangat penting dikaitkan dengan perlindungan konsumen, selain itu dalam UUPK telah disinggung mengenai pelaku usaha, konsumen, tanggung jawab, kerugian, kompensasi, ganti rugi dan lain sebagainya. Termasuk dalam hal perparkiran yang besar kemungkinan timbul resiko di area perparkiran serta persengketaan antara pelaku usaha dan konsumen. Dalam UUPK mewajibkan para pihak, terutama pelaku usaha untuk mengasuransikan kendaraan bermotor atau yang menjadi obyek parkir. Adanya nota kesepahaman atau MOU antara pelaku usaha dan pihak asuransi untuk lebih melindungi dan memberikan kepastian hukum terhadap konsumen ataupun pelaku usaha itu sendiri. Dengan demikian tujuan dari perlindungan konsumen lebih tercapai, sehingga perlindungan dan kepastian yang diharapkan masyarakat dapat terwujud.

\section{DAFTAR PUSTAKA}

Miru, Ahmadi, Prinsip-Prinsip Perlindungan Hukum Bagi Konsumen Di Indonesia. Jakarta : Raja Grafindo Persada, 2011.

Muchsin. 2009, Tugas dan Wewenang Peradilan Terhadap Putusan Badan Penyelesaian Sengketa Konsumen, dalam Varia Peradilan, No. 278 Januari 2009. Jakarta : Mahkamah Agung Republik Indonesia, 2009.

Nasution, Az., Hukum Perlindungan Konsumen: Suatu Pengantar. Cet. 2. Jakarta : Diadit media, 2002.

Sam Ratulangi, Universitas, Pedoman Penyelenggaraan Pendidikan Progam Studi S2 IImu Hukum Pasca Sarjana Universitas Sam Ratulangi. Manado : Program Studi S2 Ilmu Hukum Program Pasca Sarjana, 2013.

Sidabalok, Janus, Hukum Perlindungan Konsumen di Indonesia. Bandung : PT. Citra Aditya Bakti, 2010.

Usman, Rachmadi, Pilihan Penyelesaian Sengketa di Luar Pengadilan. Bandung : PT. Citra Aditya Bakti, 2003.

Asshiddiqie, Jimli, dan M. Ali Safa'at, Teori Kelsen Tentang Hukum. Jakarta : Sekretariat Jenderal dan Kepaniteraan Mahkamah Konstitusi RI, 2006.
Miru, Ahmadi dan Yodo, Sutarman, Hukum Perlindungan Konsumen. Cet.1. Jakarta : Rajawali Press, 2004.

Undang-undang Republik Indonesia Nomor 8 Tahun 1999 tentang Perlindungan Konsumen

Peraturan Menteri Perdagangan Nomor 17/MDag/Per/4/2007 tentang Perlindungan Konsumen.

Lanazura, Dony, Ketentuan Hukum (Baru) yang Diatur dalam UU Perlindungan Konsumen dan Mekanisme Penyelesaian Sengketa. Makalah disampaikan pada Program Pembekalan PPDN. Jakarta : Yayasan Patra Cendekia, 2000.

Laporan Tahunan Polresta Manado TA. 2012 dan TA. 2013 tentang Laporan Kesatuan.

Putra, Tria Sasangka., S.H., LL.M., Perlindungan Konsumen dalam Era Consumerism-Wise di Indonesia. Jakarta : Harian Pelita, 2006.

Widijantoro, Ruang Lingkup Persoalan Penegakan Hukum Pelindungan Konsumen Indonesia. Diktat Hukum Persaingan dan Perlindungan Konsumen. Yogyakarta : Program Studi Magister Hukum, Universitas Atmadjaya, 2001.

Pratanto, C. 2012. "Perlindungan Konsumen". Melalui

http://cpratanto.blogspot.com/2012/12/per lindungan-konsumen.html [14/05/14]

Sukarmi. 2005. "Tanggung Jawab Pelaku Usaha Atas Kerugian Konsumen Yang Disebabkan Oleh Perjanjian Baku (Standard Contract) Dalam Transaksi Elektronik. Prinsip Tanggung Jawab". Melalui vanbanjarechts.wordpress.com/2013/01/01 /prinsip-tanggung-jawab/ [25/06/15]

Tjandrasari, Heri. 2011. "Badan Penyelesaian Sengketa Konsumen ( BPSK ) dan Upaya Perlindungan Hukum Kepada Konsumen", diterbitkan oleh MaPPI-FHUP, tahun dan tanggal terbit tidak disebutkan, diakses dari www.pemantauperadilan.com [26/02/14]

Tjandrasari, Heri. 2003. "Badan Penyelesaian Sengketa Konsumen ( BPSK ) Dan Upaya Perlindungan Hukum Bagi Konsumen", 05 Jun 2003, 14:00:15 WIB pemantauperadilan.com. Melalui http://www.pemantauperadilan.com/detil/ detil.php?id=93\&tipe=opini $[26 / 02 / 14]$ 